\title{
Biológiai terápia szisztémás alkalmazása a szemészetben
}

\author{
Benyó Fruzsina dr. - Farkas Alexandra dr. - Horváth Hajnalka dr. \\ Nagy Zoltán Zsolt dr. - Szepessy Zsuzsanna dr.
}

Semmelweis Egyetem, Általános Orvostudományi Kar, Szemészeti Klinika, Budapest

\begin{abstract}
Közleményünkben a nem fertőzéses eredetû́ uveitises, szisztémás biológiai terápiában részesülő betegeink kórtörténetét ismertetjük, ahol a szemészeti panaszok első/vezető tünetként jelentkeztek és hívták fel a figyelmet a háttérben rejlő autoimmun, több szervet érintő betegségre. Első esetünkben a panuveitis hátterében Vogt-Koyanagi-Haradabetegség, második esetünkben a panuveitis hátterében sarcoidosis, míg harmadik esetünkben az intermedier uveitis hátterében gyulladásos bélbetegség állt. A betegek a szemészetben újonnan bevezetett biológiai terápiában (adalimumab) részesültek, amely nemcsak az intraocularis gyulladás megszűnését, hanem a háttérbetegség aktivitásmentességét is eredményezte. A szemészetben új, szisztémás biológiai terápia, az adalimumab alkalmazása a háttérben álló autoimmun betegségek kezelése mellett a látóélesség megőrzése szempontjából is döntő jelentőségű.
\end{abstract}

Orv Hetil. 2019; 160(44): 1744-1750.

Kulcsszavak: biologikum, TNF $\alpha$-gátló, adalimumab, uveitis

\section{Systemic biological treatment in ophthalmology}

We present herewith cases of non-infectious uveitis with biological treatment where the ocular complaints were the initial symptoms indicating a multi-organ autoimmune disease. The first case was a patient with panuveitis and VogtKoyanagi-Harada disease, the second case was also a panuveitic patient with sarcoidosis and the third case was a patient with intermediate uveitis and inflammatory bowel disease. In all cases, emerging new, biological therapy (adalimumab) was necessary to achieve permanent inactive period of uveitis and the autoimmune disease. Introducing systemic biological treatment (adalimumab) in ophthalmology is crucial in the therapy of immune-mediated, noninfectious uveitis in order to preserve visual acuity.

Keywords: biological treatment, TNF $\alpha$ inhibitor, adalimumab, uveitis

Benyó F, Farkas A, Horváth H, Nagy ZZs, Szepessy Zs. [Systemic biological treatment in ophthalmology]. Orv Hetil. 2019; 160(44): 1744-1750.

(Beérkezett: 2019. június 13.; elfogadva: 2019. július 2.)

\begin{abstract}
Rövidítések
ANA $=$ antinukleáris antitest $;$ anti-VEGF $=($ antivascular endothelial growth factor) a vascularis endothelialis növekedési faktort gátló; $\mathrm{CMV}=$ cytomegalovirus; $\mathrm{CRP}=\mathrm{C}$-reaktív protein; $\mathrm{EBV}=$ Epstein-Barr-vírus; HIV = (human immunodeficiency virus) emberi immunhiány-előidéző vírus; HSVI = (herpes simplex virus type 1) 1-es típusú herpes simplex vírus; HSV2 = (herpes simplex virus type 2) 2-es típusú herpes simplex vírus; $\mathrm{IL}=$ interleukin $; \mathrm{MR}=$ (magnetic resonance $)$ mágneses rezonancia; OCT $=($ optical coherence tomography) optikaikoherencia-tomográfia; $\mathrm{TNF} \alpha=$ tumornekrózisfaktor-alfa; $\mathrm{VKH}=$ Vogt-Koyanagi-Harada-szindróma; VZV = varicella zoster vírus
\end{abstract}

A biológiai gyógyszerek térhódítása, mint az orvostudomány több területén, a szemészeti betegségek terápiájában is jelentős fejlődést hozott. A biologikumok biotechnológiai módszerekkel baktérium-, élesztő- vagy állati/humán sejttenyészetekben termelt, egyedileg azonosítható makromolekulák. A biológiai terápia lényege, hogy a komplex gyulladásos hálózat egyetlen pontján specifikusan, célzottan (például egy adott citokin szintjén) hatnak és szakítják meg az immunológiai folyamatot [1-3]. A biológiai terápiát először az onkológiában alkalmazták, ahol kifejlesztették a lymphomák kezelésére alkalmazott rituximabot és az angiogenezist gátló vascu- 
laris endothelialis növekedési faktort gátló (anti-VEGF-) szereket $[1,2]$. A szemészetben biologikumokat lokálisan (intravitrealis alkalmazás) és szisztémásan (gyulladásos szembetegségek esetén) adhatunk.

Több mint egy évtizede az időskori maculadegeneratio nedves formájában, szemfenéki vénás elzáródáshoz társuló maculaoedemában és diabeteses maculaoedemában adható intravitrealisan anti-VEGF-szer. Jelenleg a ranibizumab (Lucentis) és az aflibercept (Eylea) rendelkezik törzskönyvi indikációval a fent említett betegcsoportokban. A kezelés specifikusságát a közvetlenül az üvegtesti térbe történő alkalmazás adja, amely akár havonta ismételhető [4].

Uveitiscentrumokban 2016 óta szisztémásan, felnőttkorban az immunmediált, nem fertőzéses eredetű intermedier, hátsó és panuveitisek terápiájában alkalmazható biologikum. A TNF $\alpha$-gátlók csoportjába tartozó adalimumab (Humira) rendelkezik törzskönyvi indikációval az uveitises betegcsoportokban subcutan alkalmazásban. A teljesen humán monoklonális fehérjékből álló adalimumab a hosszú felezési ideje miatt kéthetente adandó [1-3].

Jelen közleményünk célja olyan uveitises, szisztémás biológiai terápiában részesülő betegek kórtörténetének ismertetése, ahol a szemészeti panaszok első/vezető tünetként jelentkeztek és hívták fel a figyelmet a háttérben rejlő autoimmun, több szervet érintő betegségre. A szemészetben új, szisztémás biológiai terápia bevezetése a látóélesség megőrzése mellett a háttérben álló autoimmun betegségek aktivitásmentességét is eredményezte.

\section{Esetismertetés}

\section{Elsö eset}

A 46 éves nőbeteg kétoldali látásromlással jelentkezett intézetünkben. Anamnézisében szemészeti betegség nem szerepelt. Kiemelendő gyermekkori bal oldali csípőficama, valamint néhány éve jelentkezett bal oldali csípőízületi gyulladása és gyakori fejfájása. Szemészeti vizsgálatakor a legjobb korrigált látóélessége mindkét szemén 0,6 volt. Amsler-rács segítségével mindkét oldalon centrális scotoma volt kimutatható. Réslámpás vizsgálat során mindkét oldalon érágas conjunctivát, a corneán precipitátumokat, az elülső csarnokban gyulladásos sejteket láttunk. Biomikroszkópos vizsgálat során mindkét oldalon az üvegtestben gyulladásos sejteket, kissé elmosott határú, promineáló papillát, a hátsó póluson kiterjedt serosus retinaleválást, valamint a periférián is kerek, serosus retinaleválásokat láttunk (1. ábra). Kétoldali panuveitis képével találkoztunk. Fluoreszcens angiográfiás vizsgálaton mindkét oldalon foltosan későn telődő, csökkent chorioideaperfúziót, a késői felvételeken festékhalmozást láttunk a serosus retinaleválásoknak megfelelően. A macula-OCT-vizsgálat subretinalis folyadékot mutatott a fovea alatt (2. ábra).
A beteg általános kivizsgálása során rutinlaborleletében eltérés nem volt. A tuberkulózis és sarcoidosis kizárása céljából végzett mellkasröntgen-vizsgálat nem mutatott kórosat, illetve az elvégzett 'QuantiFERONTB Gold' teszt is negatív eredménnyel zárult. A beteg infektológiai szerológiai vizsgálata során laboreltérés nem volt kimutatható (Borrelia-, Toxoplasma-, Treponema-, EBV-, HSVl-, VZV-, HSV2-, CMV-, HIV-teszteredménye negatív lett).

Betegünknél ezután neurológiai vizsgálat történt; a koponya-MR eltérést nem mutatott. Fül-orr-gégészeti konzílium során kóros eltérés nem igazolódott. Bőrgyógyászati vizsgálatakor vitiligót diagnosztizáltak.

A klinikai kép alapján inkomplett Vogt-Koyanagi-Harada-szindrómát diagnosztizáltunk, és szisztémás szteroidterápiát kezdtünk (250 mg metilprednizolon-lökésterápia). A megkezdett szisztémás szteroidterápia, valamint a lokális szteroid (dexametazon)- és pupillatágító (ciklopentolát-) terápia mellett látóélessége egy hét alatt javult $(0,8 / 1,0)$, az elülső uveitises tünetek megszüntek, serosus retinaleválása jelentősen csökkent.

Immunológiai vizsgálata során a szisztémás szteroidterápiát immunszuppresszív (ciklosprorin - $100 \mathrm{mg}$ ) terápiával egészítették ki. A szteroid csökkentése mellett azonban ( $8 \mathrm{mg}$ metilprednizolon) a gyulladásos tünetek recidiváltak, ezért a szisztémás szteroidterápiát ismét megemeltük (24 mg metilprednizolon). Mivel a szteroid dózisát a gyulladásos tünetek fellángolása nélkül tovább csökkenteni nem tudtuk, biológiai terápia (adalimumab) bevezetése mellett döntöttünk.

A biológiai terápia mellett ( $40 \mathrm{mg}$ adalimumab subcutan kéthetente) a szteroidterápiát fokozatosan elhagytuk 6 hét alatt. Az adalimumab bevezetése után két hónappal a beteg látóélessége 1,0/1,0 lett, a serosus retinaleválás teljes mértékben regrediált, a gyulladásos tünetek megszűntek, más szervi tünetek (halláskárosodás, neurológiai tünetek) nem jelentek meg (3. ábra).

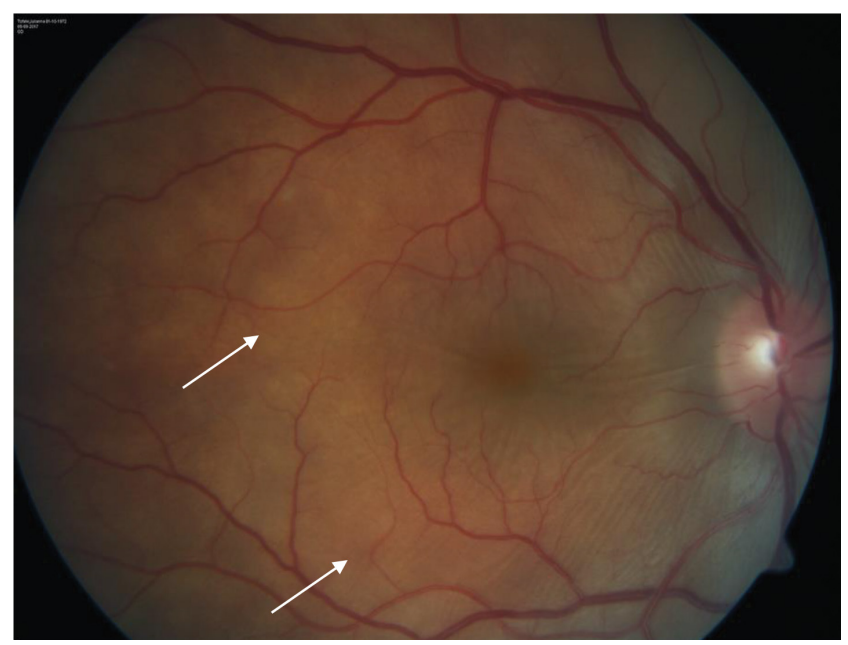

1. ábra Első esetünk jobb oldali szemfenéki képe: elmosott határú, promineáló papilla, a hátsó póluson kiterjedt serosus retinaleválás, valamint a periférián is kerek, serosus retinaleválások (fehér nyíl) láthatók (Vogt-Koyanagi-Harada-betegség) 


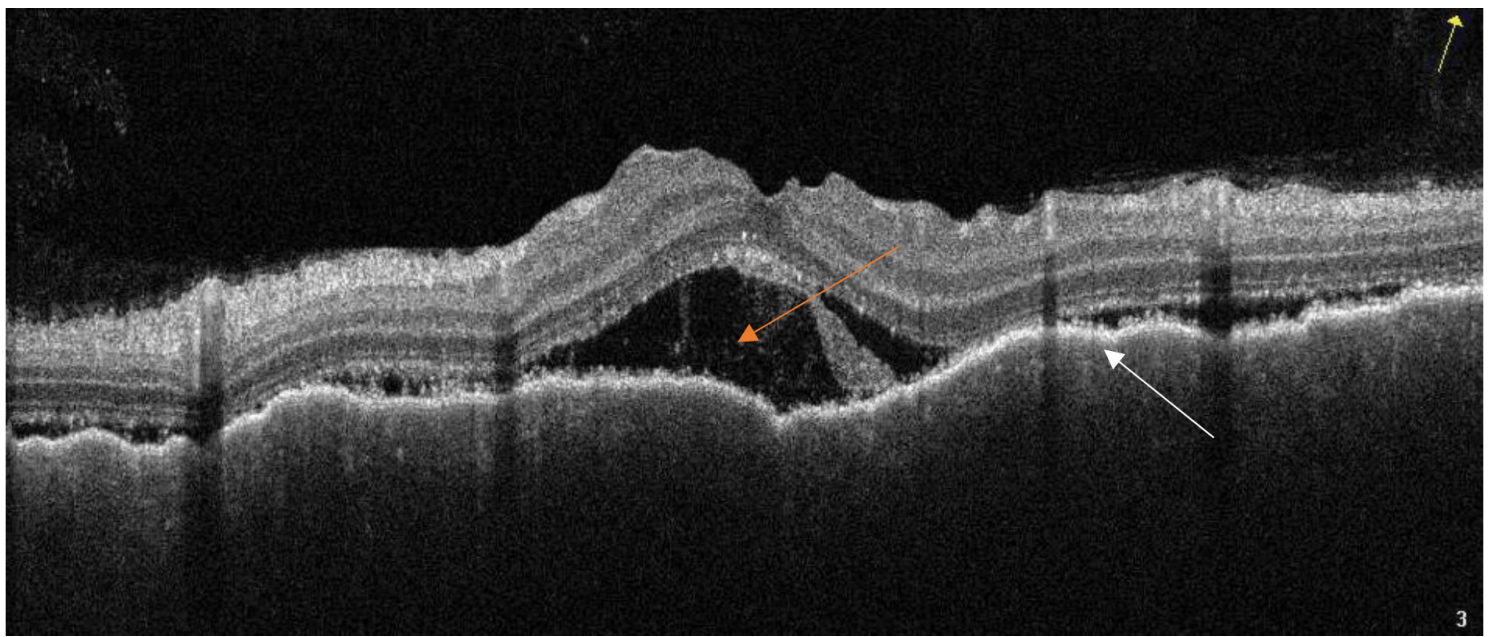

2. ábra

Első betegünk jobb szemének macula-OCT-felvétele: subretinalis folyadék (sárga nvíl) és a pigmenthám egyenetlen lefutása, redőzöttsége látható (fehér nyíl)

OCT $=$ optikaikoherencia-tomográfia

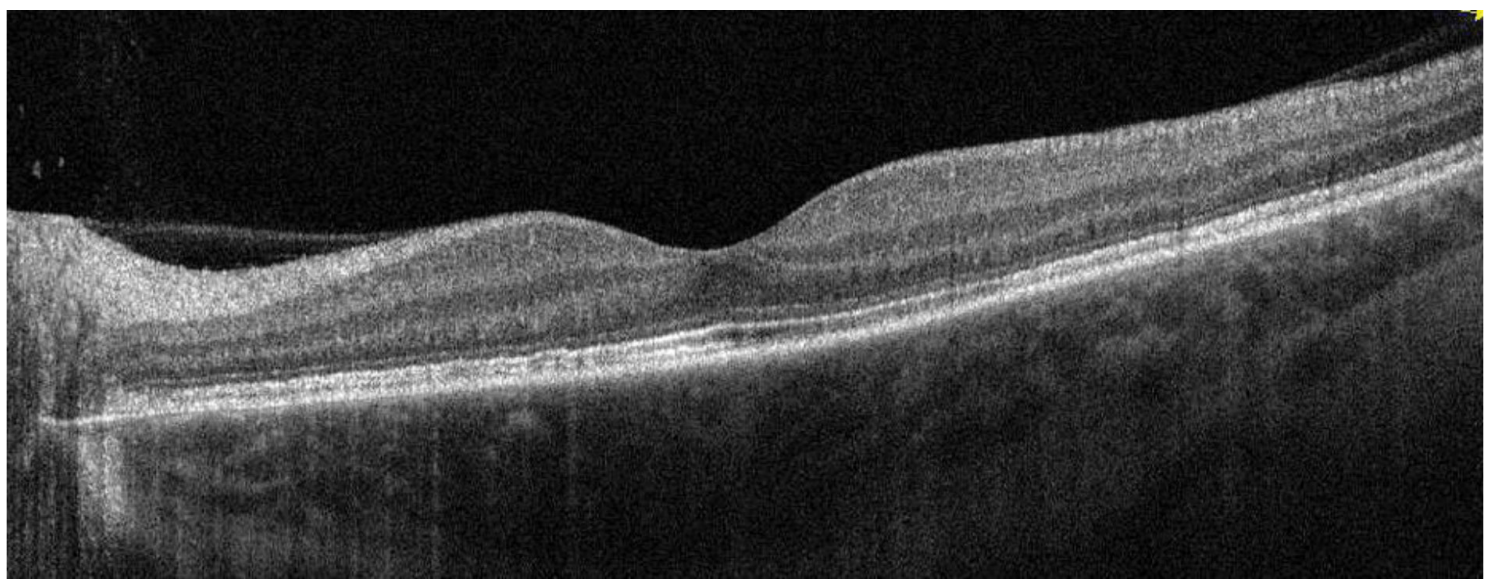

3. ábra

Első betegünk jobb szemének macula-OCT-felvétele biológiai terápia alatt: adalimumabterápia hatására a subretinalis folyadék felszívódott, a betegség aktivitása megszúnt

OCT $=$ optikaikoherencia-tomográfia

\section{Második eset}

43 éves nőbetegünk mindkét szem látásromlása miatt került intézetünkbe. Korábban mindkét szemével egyformán jól látott, szemsérülés nem érte, szemmútéte nem volt. Belgyógyászati betegségrôl nem tudott.

Szemészeti vizsgálatakor a jobb szem távoli visusa 0,1 ; a bal szem távoli visusa 0,2 volt. Réslámpás vizsgálat során mindkét oldalon ciliaris belövelltséget, a cornea hátlapján precipitátumokat találtunk, az elülső csarnok tyndallisatiójával. Jobb oldalon III és VI óra között, bal oldalon II, IV és VI óránál hátsó synechiát láttunk (4. ábra). Biomikroszkópos (superfield Volk-lencse) szemtükrözés során mindkét oldali üvegtestben sejtek voltak; az üvegtest beszúrt volt. A szemfenéken mindkét oldalon maculaoedemát diagnosztizáltunk (5. ábra).

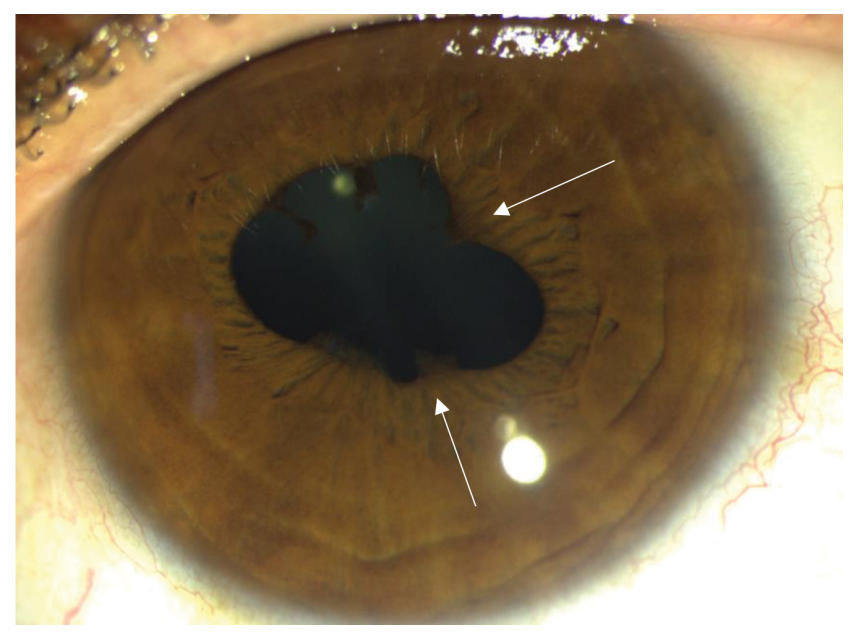

4. ábra $\mid$ Második betegünk bal szemének réslámpás felvétele: az elülső szegmentum gyulladása látható hátsó synechiákkal (nyíl) 


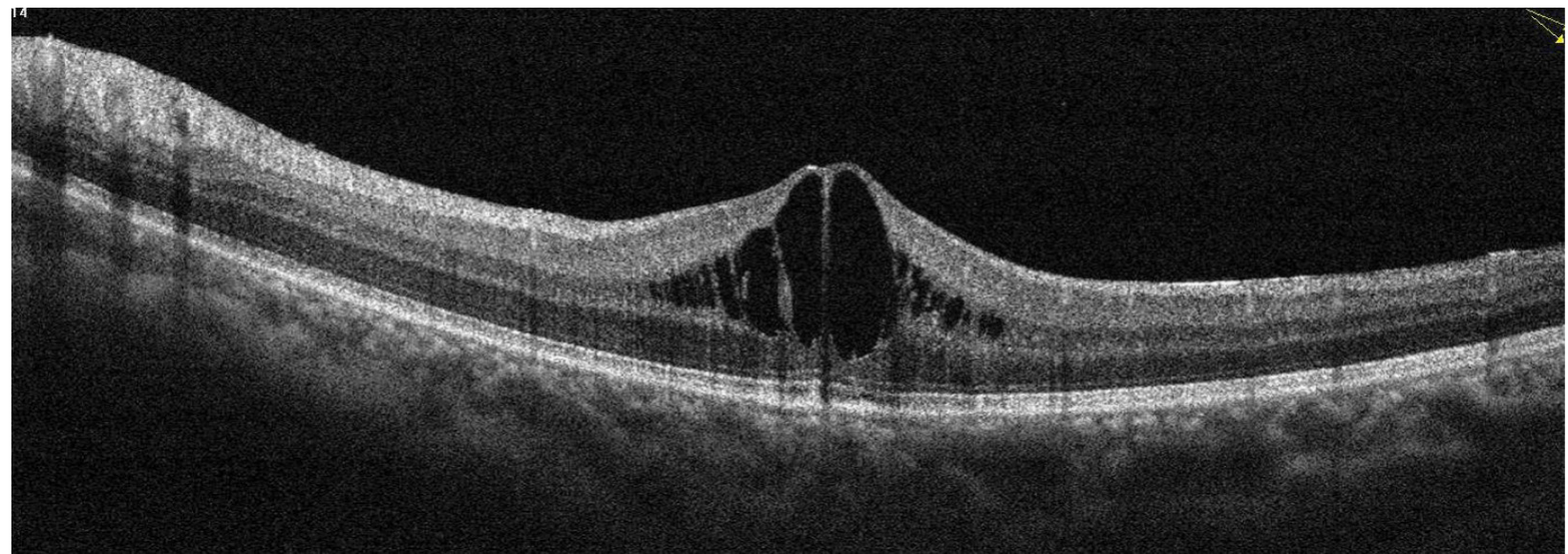

5. ábra

| Második betegünk bal szemének macula-OCT-felvétele: cystoid maculaoedema ábrázolódik

OCT $=$ optikaikoherencia-tomográfia

Általános kivizsgálása során rutinlaborleletéből kiemelendő a kissé emelkedett CRP-érték (6,4 U/1). A szerológiai vizsgálatok akut fertőzést nem igazoltak. Immunológiai laborja kromatin elleni antitest-pozitivitást, illetve az antinukleáris antitest (ANA) 1:40 és 1:160 hígításban is gyengén pozitivitást jelzett.

Mellkasröntgen-felvételén mindkét oldalon vaskosabb hilusokat, a bázison kiterjedt fibroticus rajzolatfokozódást találtak, ami alapján interszticiális tüdőbetegség volt feltételezhető. Pulmonológiai kivizsgálása során a 'QuantiFERON-TB Gold' teszt pozitív lett, ami a tuberkulózis lehetôségét is felvetette, de a köpettenyészetből Mycobacterium nem tenyészett ki, és a direkt kenetben sem találtak saválló pálcát. Ekkor mellkasi-CT-vizsgálat történt, amely bilaterális hilaris lymphadenopathiát írt le, és a bronchoszkópos tüdőbiopszia megerősítette a sarcoidosis diagnózisát.

Betegünk általános szteroidterápiában (1 mg/ttskg dózisban), valamint lokális szteroid (dexametazon)- és pupillatágító (ciklopentolát-) terápiában részesült, amelynek hatására az intraocularis gyulladás tünetei mérséklődtek. A látóélesség 2 hónap elteltével jelentősen javult: visusa a jobb szemen 0,9 , a bal szemen 0,5 volt.

A szteroid csökkentése mellett (16 mg metilprednizolon) a gyulladásos tünetek recidiváltak, és köhögés, valamint nehézlégzés is jelentkezett betegünknél, ezért a szisztémás szteroidterápiát immunszuppresszív terápiával (metotrexát) egészítették ki. Mivel a szteroid dózisát a gyulladásos tünetek fellángolása nélkül tovább csökkenteni nem lehetett, illetve a pulmonológiai tünetek is fokozódtak (légzésfunkciós paraméterei rosszabbodtak), biológiai terápiát (adalimumab) vezettünk be.

A biológiai terápia mellett ( $40 \mathrm{mg}$ adalimumab subcutan kéthetente) a szteroidterápiát elhagytuk; a beteg látóélessége jelenleg $0,9 / 0,9$. Két hónappal az adalimumab bevezetése után az intraocularis gyulladásos tünetek megszűntek, majd pulmonológiai tünetei és légzésfunkciós paraméterei is a normáltartományba kerültek.

\section{Harmadik eset}

A 29 éves nőbeteg kétoldali látásromlással, foltlátással, úszkáló homályokkal jelentkezett intézetünkben. Anamnézisében szemészeti betegség nem szerepelt, belgyógyászati betegségről nem tudott.

Szemészeti vizsgálatakor a legjobb korrigált látóélessége mindkét szemén 0,5 volt. Réslámpás vizsgálat során mindkét oldalon békés elülső szegmentumot láttunk. Biomikroszkópos vizsgálat során mindkét oldalon az üvegtestben úszó homályokat, az üvegtest perifériás részén gyulladásos sejthalmazokat („hólabda”), a hátsó póluson cystoid maculaoedemát találtunk (6. ábra). Kétoldali intermedier uveitist diagnosztizáltunk.

A beteg általános kivizsgálása során rutinlaborleletéből kiemelendő emelkedett CRP-értéke. A tuberkulózis és a sarcoidosis kizárása céljából végzett mellkasröntgen-vizsgálat nem mutatott kórosat, illetve az elvégzett 'QuantiFERON-TB Gold' teszt is negatív eredménnyel zárult. A beteg infektológiai szerológiai vizsgálata során laborel-

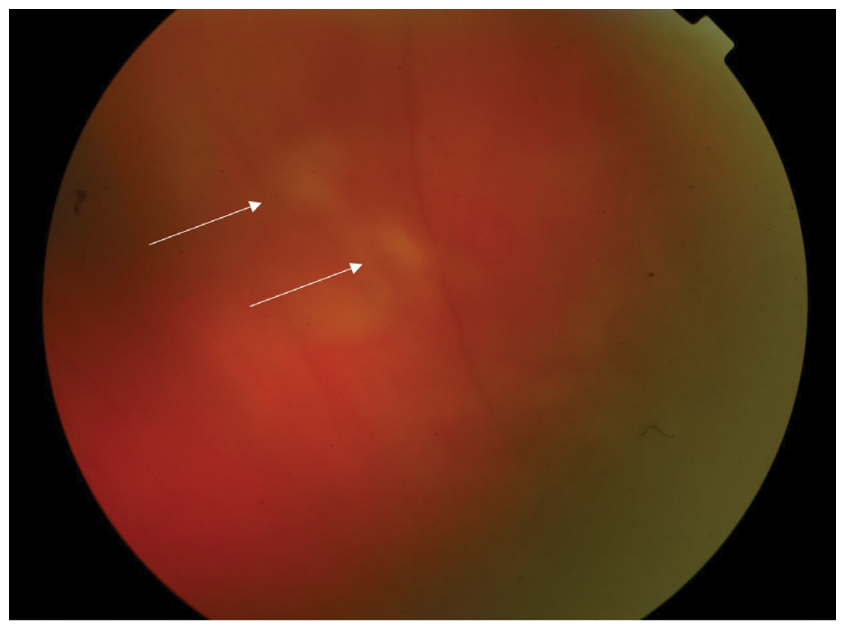

6. ábra

Harmadik esetünk jobb oldali perifériás szemfenéki képe: az üvegtest beszưrt, az üvegtest perifériás részén gyulladásos sejthalmazok („hólabda”) láthatók (fehér nyíl) 
térés nem volt kimutatható (Borrelia-, Toxoplasma-, Treponema-, EBV-, HSV1-, VZV-, HSV2-, CMV-, HIVteszt-eredménye negatív lett). Betegünknél ezután neurológiai vizsgálat történt; a sclerosis multiplex kizárása céljából végzett koponya-MR eltérést nem mutatott. Gasztroenterológiai vizsgálata gyulladásos bélbetegséget, szövettanilag igazolt Crohn-betegséget diagnosztizált.

Az elkezdett szisztémás szteroidterápia ( $1 \mathrm{mg} / \mathrm{ttskg}$ ) mellett látóélessége javult $(1,0 / 1,0)$, a maculaoedema megszűnt. Két hónappal később azonban súlyos gasztroenterológiai és szemészeti fellángolás következett be, véres hasmenéssel és uveitisszel (látásromlás mindkét szemen: látóélessége 0,2/0,3 lett). A beteg uveitise immunszuppresszív terápia mellett is aktivitást mutatott, így biológiai terápiában (adalimumab) részesült. Az adalimumab bevezetése után 7 héttel a szemészeti gyulladás aktivitása teljesen megszűnt. Intraocularis gyulladás, intermedier uveitis maculaoedemával a biológiai terápia elkezdése után nem jelentkezett, a beteg látóélessége jelenleg is $1,0 / 1,0$. Gasztroenterológiai panaszai is regrediáltak.

\section{Megbeszélés}

A szemészetben már több éve alkalmazott lokális - intravitrealis - biológiai terápia (anti-VEGF-szer: ranibizumab, aflibercept) mellett napjainkban már szisztémásan is alkalmazható uveitisben biologikum: a $\mathrm{TNF} \alpha$-gátlók csoportjába tartozó adalimumab.

A TNF $\alpha$ egy pleiotrop citokin, amelyet a gyulladásos folyamatok fó szabályozójának tartanak, a gyulladásos citokinkaszkád hierarchiájában elfoglalt helyének köszönhetően. Számos immunkompetens sejt múködését befolyásolja; hatását részben direkt módon, részben más proinflammatoricus citokinek közvetítésével fejti ki $[2,3]$. Állatkísérletek bizonyították, hogy a $\mathrm{TNF} \alpha-$ molekula kiemelkedő szerepet játszik a szem gyulladásos betegségeiben. Uveitises állatmodellekben a TNF $\alpha$-szint emelkedését és a TNF $\alpha$-receptorok számának növekedését találták. Uveitises betegeknél a szérum és a csarnokvíz TNF $\alpha$-szintjének is szignifikáns emelkedése mutatkozott, bizonyítva ezen molekula kiemelkedő szerepét a szem gyulladásaiban [3].

A TNF-blokkolók monoklonális antitestekre (infliximab, adalimumab, golimumab és certolizumab pegol) és receptorfúziós proteinre (etanercept) oszthatók [1-3]. Jelenleg hazánkban a TNF-inhibitorok közül csak az adalimumab rendelkezik törzskönyvi indikációval a szemészetben. Az adalimumab már teljesen humán monoklonális antitest hosszú felezési idővel (14 nap), és subcutan alkalmazása könnyebb elérhetőséget is lehetővé tesz (1. táblázat).

Első esetünkben egy ritka betegségben, a Vogt-Koyanagi-Harada (VKH)-szindrómában elsőként alkalmaztunk hazánkban biológiai terápiát. A VKH-szindróma multiorganikus, ritka autoimmun betegség, amelynek
1. táblázat $\mid$ Az adalimumab alkalmazásai, indikációi hazánkban

\begin{tabular}{l}
\hline - Gyulladásos izuileti betegségek: \\
- rheumatoid arthritis \\
- juvenilis idiopathiás arthritis (JIA): polyarticularis és enthesitis- \\
asszociált, gyermekkori arthritis psoriatica \\
- arthritis psoriatica \\
- nem röntgen axialis spondylarthritis \\
- spondylitis ankylopoetica \\
- Gyulladásos bélbetegségek: \\
- Crohn-betegség \\
- colitis ulcerosa \\
- gyermekkori Crohn-betegség \\
- Pikkelysömör, gyermekkori pikkelysömör \\
- Felnôtttkori, nem fertözéses eredetü intermedier, hátsó uveitis, \\
panuveitis \\
- Gyermekkori, nem fertözéses eredetü krónikus elülsö uveitis \\
\hline
\end{tabular}

2. táblázat | Diagnosztikus kritériumok Vogt-Koyanagi-Harada-betegség ben

1. Az anamnézisben nem szerepel penetráló szemsérülés vagy bulbusmegnyitó mütét

2. Más szisztémás, autoimmun betegség kizárható

3. Kétoldali szemészeti megbetegedés

a) Korai manifesztációk: diffúz chorioiditis fokális subretinalis folyadék megjelenésével vagy bullosus serosus retinaleválásokkal

- Fluoreszcens angiográfiás vizsgálattal csökkent chorioideaperfúzió, pinpoint (kis pontszerü) festékszivárgás a korai felvételeken, míg a késői felvételeken festékhalmozás a serosus retinaleválásoknak megfelelően

- Ultrahangon diffúz chorioideamegvastagodás posterior scleritis nélkül

b) Késői manifesztációk: ocularis depigmentáció - „sunset glow” fundus vagy Sugiura-jel

más szemészeti tünetek: chorioretinalis depigmentációs hegek, pigmentsejt, vándorlás” a funduson, recidiváló vagy krónikus elülső uveitis

4. Neurológiai/fül-orr-gégészeti eltérések
a) Meningismus
b) Tinnitus
c) Liquorpleocytosis

5. Börgyógyászati eltérések
a) Alopecia
b) Poliosis
c) Vitiligo

szemészeti, fül-orr-gégészeti, neurológiai és bőrmanifesztációja ismert. A betegség jellegzetes szemészeti tünete a kétoldali, krónikus, granulomatosus panuveitis (2. táblázat). A komplett formára a szemészeti, neurológiai és bőrmanifesztáció együttes megjelenése jellemző. Inkomplett forma esetén a szemészeti tünetekhez neu- 
rológiai vagy bőrpanaszok társulnak. Feltételezett VKHbetegség esetén uveitis extraocularis manifesztáció nélkül alakul ki $[5,6]$.

A VKH-szindróma adekvát terápiáját az akut fázisban alkalmazott kortikoszteroidok jelentik, melyet a későbbi stádiumokban immunmoduláns kezelés válthat fel [6]. Betegünk azonban immunszuppresszív kezelésre rezisztensnek bizonyult, a szteroidot a gyulladásos tünetek fellángolása nélkül nem tudtuk $20 \mathrm{mg}$ alá csökkenteni, így az új kezelési lehetőséget, a TNF $\alpha$-gátló adalimumabterápiát választottuk. A biológiai terápiára a betegség aktivitásmentessé vált, a beteg látóélessége javult, emellett új neurológiai, fülészeti, bőrgyógyászati tünetek sem alakultak ki.

Második esetünkben a panuveitis kialakulása több hónappal megelőzte a háttérbetegség, a sarcoidosis jellegzetes tüneteit. Esetünk érdekességét és nehézségét a tuberkulózis és a sarcoidosis differenciáldiagnosztikája jelentette. A két megbetegedés szemészeti megjelenési formái hasonlóak, granulomatosus panuveitisként jelentkezhetnek. Szemészeti szempontból, csak az intraocularis tünetek alapján nem különíthetők el egymástól, szükségesek a laboratóriumi és képalkotó vizsgálatok $[7,8]$. Betegünknél a tuberkulózis lehetőségére a 'QuantiFERON-TB Gold' teszt pozitivitása hívta fel a figyelmet. Sarcoidosisban azonban a QuantiFERON-vizsgálat álpozitivitást mutathat, ami esetünkben is fennállt. Az angiotenzinkonvertáló enzim szérumbeli emelkedése is alátámaszthatja a sarcoidosis diagnózisát, de az irodalmi adatok alapján tuberkulózisban is emelkedett lehet ez az érték [7]. A képalkotó vizsgálattal, a nagy felbontású mellkasi-CT-felvételekkel azonban az interszticiális tüdőbetegség és lymphadenopathia már egyértelmúen kimutatható. Szövettani vizsgálattal (bronchoszkópos tüdőbiopszia) bizonyítást nyert esetünkben is a sarcoidosis dignózisa. A sarcoidosis prognózisa szemészeti érintettségben jó, ha időben felismerésre kerül $[9,10]$.

Ocularis sarcoidosisban bilaterális, hátulsó szegmentumi érintettség esetén szisztémás szteroidterápia indítandó. Azoknak a betegeknek, akik szteroidra nem megfelelően reagálnak, vagy súlyos mellékhatások jelentkeznek, immunszuppresszió vagy biológiai terápia adható [9]. Esetünkben a biológiai terápiára nemcsak a szemészeti, hanem az uveitis után jelentkező pulmonológiai tünetek is megszúntek.

Harmadik esetünkben az uveitis tünetei szintén megelőzték a gyulladásos bélbetegség diagnózisát. Kétoldali, nem fertőzéses eredetû, intermedier uveitisben, amikor a corpus ciliare pars plana területén zajlik a gyulladás, mindig gondolni kell a sclerosis multiplex, a sarcoidosis és a gyulladásos bélbetegségek lehetôségére [11]. Esetünkben szövettanilag igazolt Crohn-betegséget diagnosztizáltunk, amely biológiai terápiára (adalimumab) jól reagált.

Eseteinkben az adalimumab bevezetése után 7-8 héttel következett be a szemészeti gyulladás megszúnése.
Az irodalomban is 6-10 hét utáni aktivitásmentességgel találkozhatunk.

Ha 12-16 hét után nem következik be javulás, mindenképpen a biológiai terápia módosítását javasolják $[1,12]$.

A jövő kérdését az új biológiai terápiás szerek jelenthetik. Sok multicentrikus klinikai tanulmány folyik napjainkban is a szemészeti gyulladások terén [3, 12-14]. Sokat közülük más szakterületeken - például reumatológia - már törzskönyveztek. A gevokizumab és a canakinumab egy-egy speciális humanizált monoklonális antitest, amelyek az ILI $\beta$-hoz kötődnek. A jövő nagy lehetőségeinek tartják őket a nem fertőzéses uveitisek kezelésében. Multicentrikus klinikai tanulmányok folynak jelenleg a gevokizumab subcutan alkalmazásával Behçet-uveitisben és aktív, nem infekciózus uveitisben [3, 12]. A másik reménység lehet a receptorantagonisták csoportjába tartozó tocilizumab, amely egy IL6-receptor elleni monoklonális antitest. Behçet-kórhoz társuló uveitisben, uveitises maculaoedemában és különböző retinalis vasculitisekben is eredményesnek találták [14]. TNF-gátlókra rezisztens esetekben is biztató eredményeket mutatott [14]. A jövő izgalmas kérdése lehet még a lokálisan adható TNF $\alpha$ gátló terápia. A szemészetben már jól bevált és alkalmazott intravitrealis szteroidimplantátumok vagy a maculadegeneratióban engedélyezett ranibizumab- és afliberceptkezelés beváltotta a hozzá füzött reményeket, ugyanis ezáltal a gyógyszerek szisztémás mellékhatásai csökkenhetnek, megszű́nhetnek $[13,15]$.

A TNF $\alpha$-gátló szerek - így az adalimumab - szisztémás mellékhatásai közül a tuberkulózis kialakulását, reaktivációját kiemelnénk, amelyet az átlagosnál gyakrabban figyeltek meg, és amely miatt rendszeres pulmonológiai kontroll szükséges ezen betegeknél. További szisztémás mellékhatás a fertőzésekre való fogékonyság. A késői mellékhatások közé tartozhat (bár az eddigi eredmények ellentmondásosak) a demyelinisatiós betegségek kialakulása és a malignus betegségek előfordulásának fokozódása. Kutatócsoportok vizsgálják a TNF $\alpha$ ellenes kezelés és a demyelinisatio/malignus kórképek közötti összefüggést, de az eredmények napjainkban nem egyértelmúek. Több munkacsoport inkább a tartós gyulladás szervezetben való meglétét tartja nagyobb rizikónak a daganatos betegségek kialakulásában, mint a biológiai terápiát. Az elmúlt évek tapasztalatai és a gyógyszer-biztonságossági eredmények alapján a TNF $\alpha$-gátló kezelés az elő́rások betartásával biztonságosan alkalmazható $[3,12]$.

Közleményünkkel szerettük volna felhívni a figyelmet az autoimmun uveitisek új terápiás lehetőségeire, a szisztémás autoimmun betegségek vezetô szemészeti tüneteire és az interdiszciplináris összefogás fontosságára, mert a betegek komplex diagnosztikája és kezelése így válhat teljessé. Eseteinkben a szemészeti tünetek első tünetként jelentkeztek, amelyek szisztémás autoimmun betegségek részjelenségeinek bizonyultak. 
A szisztémás biológiai terápia (adalimumab) bevezetése a szemészetben, az immunmediált uveitisek kezelésében döntő jelentőségú. Az eseteinkben alkalmazott biológiai terápia hatására nemcsak az intraocularis gyulladások, hanem a háttérbetegségek aktivitásmentessége is elérhetővé vált. A biologikumok alkalmazása során a különböző szakterületek orvosainak együttmúködésére, összehangolt munkájára nagy szükség van a betegek látóélességének megőrzése szempontjából is.

Anyagi támogatás: A közlemény megírása, illetve a kapcsolódó kutatómunka anyagi támogatásban nem részesült.

Szerzôi munkamegosztás: Sz. Zs: A vizsgálat tervezése. B. F., F. A., H. H.: A vizsgálatok elvégzése. B. F., Sz. Zs.: A közlemény megírása. N. Z. Zs.: A közlemény kritikai revíziója. A cikk végleges változatát valamennyi szerző elolvasta és jóváhagyta.

Érdekeltségek: A szerzőknek nincsenek érdekeltségeik.

\section{Irodalom}

[1] Poór G. Biological therapy in the rheumatology practice in Hungary. [Biológiai terápia a hazai reumatológiai gyakorlatban.] Medicina Könyvkiadó, Budapest, 2017. [Hungarian]

[2] Szekanecz Z. (ed.) Pharmacological treatment in rheumatology. [Reumatológiai gyógyszeres terápia.] Medicina Könyvkiadó, Budapest, 2009. [Hungarian]

[3] Saadoun D, Bodaghi B, Bienvenu B, et al. Biotherapies in inflammatory ocular disorders: interferons, immunglobulins, monoclonal antibodies. Autoimmun Rev. 2013; 12: 774-783.

[4] Rofagha S, Bhisitkul R, Boyer D, et al. Seven-year outcomes in ranibizumab-treated patients in ANCHOR, MARINA, and HORIZON: a multicenter cohort study (SEVEN-UP). Ophthalmology 2013; 120: 2292-2299.

[5] Yang P, Zhong Y, Du L, et al. Development and evaluation of diagnostic criteria for Vogt-Koyanagi-Harada disease. JAMA Ophthalmol. 2018; 136: 1025-1031.

[6] Zhao GL, Li RZ, Pang YH, et al. Diagnostic function of 3D optical coherence tomography images in diagnosis of VogtKoyanagi-Harada disease at acute uveitis stage. Med Sci Monit. 2018; 24: 687-697.

[7] Gupta A, Sharma A, Bansal R, et al. Classification of intraocular tuberculosis. Ocul Immunol Inflamm. 2015; 23: 7-13.

[8] Szepessy Zs. Uveitis in sarcoidosis. [Uveitis sarcoidosisban.] Orv Hetil. 2013; 154: 1798-1801. [Hungarian]

[9] Baughman RP, Lower EE, Ingledue R, et al. Management of ocular sarcoidosis. Sarcoidosis Vasc Diffuse Lung Dis. 2012; 29: 26-33.

[10] Miserocchi E, Modorati G, Di Matteo F, et al. Visual outcome in ocular sarcoidosis: retrospective evaluation of risk factors. Eur J Ophthalmol. 2011; 21: 802-810.

[11] Babu BM, Rathinam SR. Intermediate uveitis. Indian J Ophthalmol. 2010; 58: 21-27.

[12] Suhler EB, Lowder CY, Goldstein DA, et al. Adalimumab therapy for refractory uveitis: results of a multicentre, open-label, prospective trial. Br J Ophthalmol. 2013; 97: 481-486.

[13] Ibrahim MA, Sepah YJ, Watters A, et al. One-year outcomes of the SAVE study: sirolimus as a therapeutic approach for uveitis. Transl Vis Sci Technol. 2015; 4: 4.

[14] Papo M, Bielefeld P, Vallet H, et al. Tocilizumab in severe and refractory non-infectious uveitis. Clin Exp Rheumatol. 2014; 32: S75-S79.

[15] Myers AC, Ghosh F, Andréasson S, et al. Retinal function and morphology in the rabbit eye after intravitreal injection of the TNF alpha inhibitor adalimumab. Curr Eye Res. 2014; 39: 1106-1116.

(Szepessy Zsuzsanna dr., Budapest, Üllői út 26., 1085 e-mail: szepzsu@yahoo.com)

\section{"Late ignis lucere, ut nihil urat, non potest." (Csak ha éget, úgy világít messze a tűz.)}

A cikk a Creative Commons Attribution 4.0 International License (https://creativecommons.org/licenses/by/4.0/) feltételei szerint publikált Open Access közlemény, melynek szellemében a cikk bármilyen médiumban szabadon felhasználható, megosztható és újraközölhetö, feltéve, hogy az eredeti szerző és a közlés helye, illetve a CC License linkje és az esetlegesen végrehajtott módositások feltüntetésre kerülnek. (SID_1) 